\title{
Seasonal Growth, Phenology and Spore Shedding in Polysiphonia platycarpa Borgesen (Ceramiales, Rhodophyta) of Visakhapatnam Coast, India
}

\author{
G. Subba Rangaiah*, S. Sudhakar and E. Vanilla Kumari \\ Department of Botany, Andhra University, Visakhapatnam - 530 003, A.P. INDIA
}

\begin{abstract}
Variation in seasonal growth, phenology and periodicity in spore shedding in Polysiphonia platycarpa Børgesen occurring on the coast of Visakhapatnam, India, have been described to know the growth behaviour, reproductive periodicity and spore producing capacities. This alga occurs for a short period from December to May in the intertidal region of the Visakhapatnam coast, showing maximum growth during January/February. Tetrasporophytic, carposporophytic and antheridial plants were observed in all months of their occurrence in the field. But the vegetative plants were not seen in January and February and all the plants collected were reproductive. The tetraspore and carpospore shedding was observed during all the six months of their occurrence.
\end{abstract}

Key Words: growth, phenology, Polysiphonia platycarpa, Rhodophyta, spore shedding

\section{INTRODUCTION}

Many investigations on the species of Polysiphonia reveal only the general growth and reproductive periodicity (Conover 1964; Edwards 1970; Coleman and Mathieson 1975; Reynolds and Mathieson 1975; Agadi and Untawale 1978; Kapraun 1978; Mathieson et al. 1981; Yarish and Edwards 1982). No detailed studies were made on the spore producing capacity of Polysiphonia species. Detailed investigations were made on the ecology and physiology of some Ceramiales of the Visakhapatnam coast (Sudhakar 1992) and in this paper, only the growth, phenology and spore shedding of Polysiphonia platycarpa were described. Species of Polysiphonia are also economically important, since Polysiphonia ferulaceae consists of $13-16 \%$ of proteins (Dave et al. 1987).

\section{MATERIALS AND METHODS}

The material for the present study was collected randomly from the infralittoral fringe zone at fortnightly intervals from the Visakhapatnam Coast $\left(17^{\circ} 41^{\prime} 45^{\prime \prime} \mathrm{N}\right.$

${ }^{*}$ Corresponding author and $83^{\circ} 16^{\prime} 22^{\prime \prime}$ ) from December 1987 to May 1988. Twenty five to thirty tufts or plants of Polysiphonia platycarpa were brought to the laboratory in polyethylene bags containing seawater and used for the estimation of growth and spore liberation experiments. Details of the methods followed for analyzing the growth and fruiting behaviours have been described by Kaliaperumal and Umamaheswara Rao (1982) and Subba Rangaiah (1983). The percentage frequency of carposporophytes, antheridial and tetrasporophytes and vegetative plants present in the samples was estimated. The length of the erect filaments in different phases was measured to estimate the mean length of the carposporophytes, antheridial, tetrasporophytes and vegetative plants. Methods used for liberation and estimation of spores are followed from the previous papers published by Subba Rangaiah (1983), Subba Rangaiah and Umamaheswara Rao (1983). An average of eight to ten replicates were used every month for estimating the tetraspore and carpospore outputs and the data collected on day one are plotted in Figs 1 E \& F.

\section{RESULTS}

Data collected on seasonal variation in the mean length of the erect filaments of all generations in the 
Table 1. Percentage frequency of sexual, tetrasporic and vegetative plants in the population of Polysiphonia platycarpa

\begin{tabular}{lccccccc}
\hline Year 1988-89 & December & January & February & March & April & May & Mean \\
\hline Cystocarpic plants & 40.0 & 43.3 & 44.1 & 37.9 & 32.0 & 39.1 & 39.4 \\
Antheridial plants & 20.0 & 16.6 & 9.3 & 24.1 & 24.0 & 17.3 \\
Tetrasporic plants & 33.3 & 40.0 & 46.5 & 31.0 & 28.0 & 21.7 \\
Vegetative plants & 6.6 & 0 & 0 & 6.8 & 16.0 & 21.7 \\
\hline
\end{tabular}
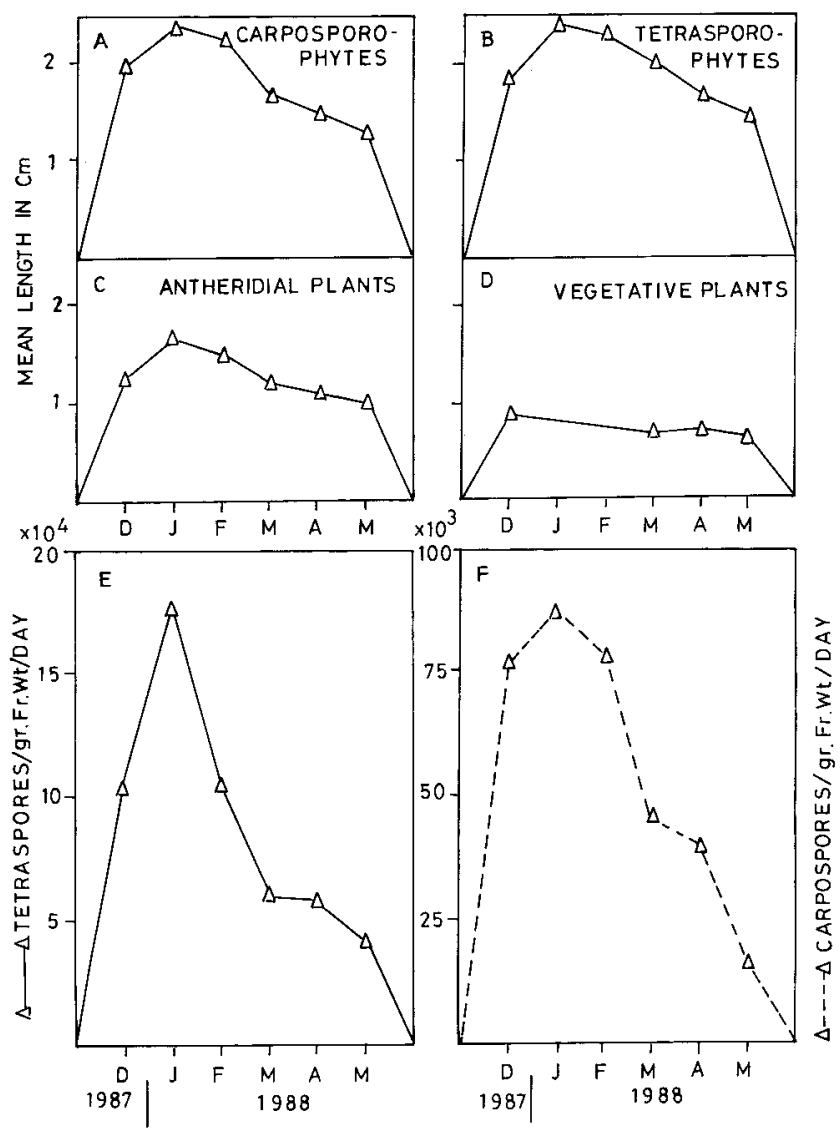

Fig. 1. Seasonal changes in growth behaviour and spore output of Polysiphonia platycarpa. A. Monthly variation in Carposporophytes. B. Monthly variation in tetrasporophytes. C. Monthly variation in antheridial plants. D. Monthly variation vegetative plants. E. Monthly variation in tetraspore output. F. Monthly variation in carpospore output.

population, mean length of the carposporic, antheridial, tetrasporic and vegetative or undeterminable fronds are shown in Fig. 1. Populations of Polysiphonia platycarpa occur (Figs 1A to D) for only six months i.e. from December to May. The plants attained their maximum size during January/February and from there onwards slow decrease in size was noticed upto May and after May onwards, no plants were seen in the field. Similar growth behaviour was noticed in the carposporophytic,
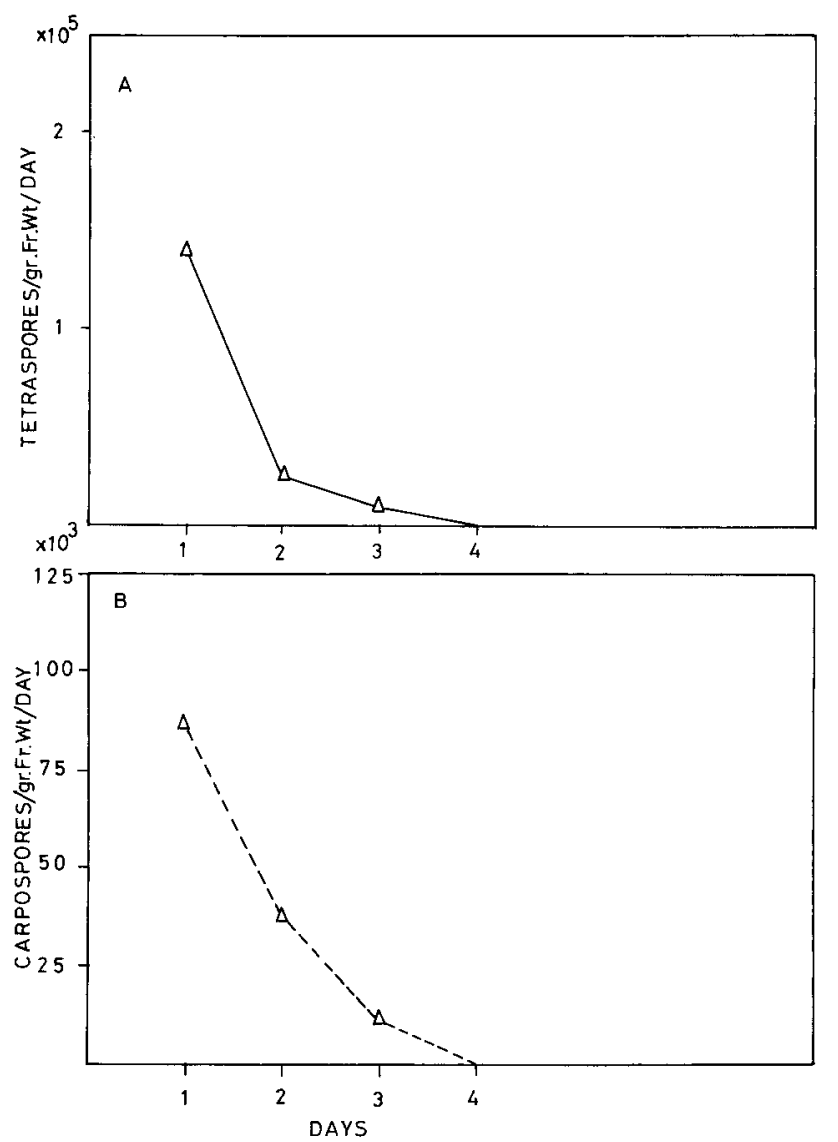

Fig. 2. Daily liberation of spore output of Polysiphonia platycarpa. A. Changes in tetraspores. B. Changes in carpospores

antheridial, tetrasporophytic and also in the vegetative plants (Figs 1A to D) and all the phases were observed and collected in all the six months of its occurrence in the field. The vegetative plants were found to be smaller in size than the sexual and tetrasporic plants.

Monthly percentage frequency of sexual, tetrasporic and vegetative plants collected from December 1987 to May 1988 are given in Table 1. From the yearly means shown in the last column of Table 1, it is evident that the percentage occurrence of fruiting plants varied. In general $91 \%$ of reproductive plants were recorded in Polysiphonia platycarpa. The relative preponderance of 
cystocarpic, antheridial and tetrasporic plants vary significantly. Cystocarpic plants were found to be almost double the number of antheridial plants. Plants of asexual generations (tetrasporic) were not more abundant than sexual generations and it is surprising to note that the asexual plants were roughly half the number of sexual plants (Table 1). In the maximum growth period i.e., during January/February, all the plants collected are reproductive.

Daily liberation of tetraspores and carpospores is shown in Fig. 2. Maximum liberation of tetraspores and carpospores was seen on day one and the spore output decreased rapidly from day two onwards and the spore shedding lasts for 3 to 4 days only (Fig. 2). Mean monthly values of tetraspores and carpospores estimated from December 1987 to May 1988 are depicted in Figs 1E and F. Spore shedding was observed in all the six months of its occurrence in the field. The tetraspore and carpospore shedding was maximum during December to February. The spore shedding varied from 43,515 to 178,697 tetraspores $\cdot \mathrm{gr}^{-1} \mathrm{fw} \cdot \mathrm{day}^{-1}$ and 16,580 to $86,994 \mathrm{car}$ pospores $\cdot \mathrm{gr}^{-1} \mathrm{fw} \cdot \mathrm{day}^{-1}$.

\section{DISCUSSION}

The data collected on the seasonal growth behaviour of Polysiphonia platycarpa indicate that the alga is present only for six months in the intertidal region of the Visakhapatnam Coast. Both sexual and asexual plants show maximum growth during January/February. This growth period of $P$. platycarpa is in conformity with the growth behaviour of the Polysiphonia species reported from Visakhapatnam Coast (Umamaheswara Rao and Sreeramulu 1964) and from West Coast, Goa (Agadi and Untawale 1978) but differs from that of Polysiphonia species reported from other geographical areas where the species are available throughout the year (Conover 1964; Edwards 1970; Reynolds and Mathieson 1975; Kapraun 1977, 1978). Seasonal occurrence of different Polysiphonia species as observed in the present study was reported by Yarish and Edwards (1982); Cheung and Hodgkiss (1984); Hanisak and Blair (1988). Bimodel growth curve has been observed by Conover (1964) in Polysiphonia ferulaceae. This type of bimodal growth curves were obtained in other genera occurring on the Visakhapatnam coast, for example in Centroceras clavulatum, Wrangelia argus (Sudharkar 1992), Gracilaria corticata (Subba Rangaiah 1983), Hypnea valentiae (Subba Rangaiah and Umamaheswara Rao 1983), Amphiroa frag- ilissima (Subba Rangaiah and Vanilla Kumari 1997) Jania rubens and Grateloupia lithophila (Vanilla Kumari 1997). Sand movement on the shore might be the influencing factor on the growth of Polysiphonia at Visakhapatnam coast as reported in other coastal areas with outcrops of boulders (Daly and Mathieson 1977). Sand cut normally occurs from October to April and filling up of the beach from May to September (Umamaheswara Rao and Sreeramulu 1964). Algae like Polysiphonia platycarpa growing in the infralittoral fringe are mainly affected by these changes in sand levels in the shore, since this alga occurs on the rocks in the period of sand cut and disappears during the period of sand filling from June to November.

Size differences in the male, female and tetrasporic plants were reported by Austin (1960) in Furcellaria fastigiata, Waern (1952) and Garbary et al. (1978) in Ceramium tenuicorne and C. rubrum. Such variations in the size of the reproductive plants of Polysiphonia platycarpa were also observed in the present study. The vegetative and male plants were found to be smaller than the cystocarpic and tetrasporic plants as observed in Centroceras clavulatum and Wrangelia argus (Sudhakar 1992). The reason for the smaller size of vegetative plants, might be that they may later develop into fruiting plants after attaining certain size. Seasonality in the occurrence of different fruiting plants of various species of Polysiphonia was reported (Dixon 1970; Edwards 1970; Coleman and Mathieson 1975, Kapraun 1978; Mathieson et al. 1981; Yarish and Edwards 1982). However, in the present study, the sexual and tetrasporic plants were collected in all the six months of the occurrence of the alga in the field. Davis and Wilce (1987) had reported the presence of Polysiphonia urceolata throughout the year without any reproductive structures.

In the reproductive cycle of the red algae, there is a general dominance of the tetrasporophytic phase. Thus Dixon (1970) explained that in Europe, tetrasporophytic plants are more often reported than sexual plants. In the species of Hypnea (Mshigeni 1976; Rama Rao 1977; Subba Rangaiah and Umamaheswara Rao 1983), Polysiphonia (Kparaun 1978), Gelidium (Montalva and Santalices 1981, Kaliaperumal and Umamaheswara Rao 1986) and Gracilaria (Umamaheswara Rao 1973; Hoyle 1978; Subba Rangaiah 1983) the sexual plants formed a small proportion of the populations. In contrast, Cheung and Hodgkiss (1984) reported no significant differences in the proportions of sexual and asexual plants in Polysiphonia harlandii and Sudhakar (1992) in Centroceras 
clavulatum and Wrangelia argus. Umamaheswara Rao and Sreeramulu (1970) also reported a kind of balance between the two phases. But in the present study, to our surprise, the sexual plants formed a large proportion $(57.9 \%)$ of the population than asexual plants (33.4\%).

The number of tetraspores and carpospores released on day one was maximum (Fig. 2). A similar trend was reported in Gracilaria edulis by Rama Rao and Thomas (1974), Gracilaria corticata by Umamaheswara Rao (1976), Subba Rangaiah (1983), G. textorii and Gracilariopsis sjoestedtii by Subba Rangaiah, (1984, 1985), Gelidium spp. by Suto (1950); Umamaheswara Rao (1974); Kaliaperumal and Umamaheswara Rao (1986), Pterocladia heteroplatos and Gelidiopsis variabilis by Kaliaperumal and Umamaheswara Rao (1982, 1985), some species of red algae by Boney (1960); Hypnea valentiae by Subba Rangaiah and Umamaheswara Rao (1983); Centroceras clavulatum, Wrangelia argus (Sudharkar 1992), Amphiroa fragilissima by Subba Rangaiah and Vanilla Kumari (1997), Jania rubens and Grateloupia lithophila by Vanilla Kumari (1997). This indicates that the plants collected from the field liberates maximum number of their spores on day one and slowly the number of spore shedding decreases from day two onwards and further it is assumed that the development of cystocarps and tetrasporangia are slow in the laboratory, thereby the shedding of spores is low from day two onwards. Corresponding with the maximum growth period, peak shedding of tetraspores and carpospores was observed during December/February (Fig. 1).

\section{REFERENCES}

Agadi V.V. and Untawale A.G. 1978. Mrine algal flora of Goa Coast. Seaweed Res. Utln. 3: 56-70.

Austin A.P. 1960. Observations on Furcellaria fastigiata (L.) Lam. Forma aegagrophila reinke in Danish waters together with a role on unattached forms. Hydrobiologia 14: 255-277.

Boney A.D. 1960. Observations on the spore output of some common red algae. Br. Phycol. Bull. 2: 36-37.

Cheung K.W. and Hodgkiss I.J. 1984. The occurrence of tetrasporangia and cystocarps on the same thalli in Polysiphonia harlandii (Rhodophyta, Ceramiales). Bot. Mar. 27: 571-572.

Coleman D.C. and Mathieson A.C. 1975. Investigations of New England Marine Algae. VII. Seasonal occurrence and reproduction of Marine algae near Cape Cod, Massachussetts. Rhodora 77: 76-104.

Conover J.T. 1964. The ecology, seasonal periodicity and distribution of benthic plants in some Texas lagoons. Bot. Mar. 7: $7-41$.
Daly M.A. and Mathieson A.C. 1977. The effects of sand movement on intertidal seaweeds and selected invertebrates at Bound Rock, New Hampshire, USA. Mar. Biol. 43: 45-55.

Dave M.J., Parekh R.G., Ramavat B.K., Doshi Y.A. and Chouhan V.D. 1987. Protein contents of red seaweeds from Gujarat coast. Seaweed Res. Utln. 10: 17-20.

Davis A.N. and Wilce R.T. 1987. Floristics, phenology and ecology of the sublittoral marine algae in an unstable cobble habitat (Plam Cove, Cape Ann, Massachassettes, USA). Phycologia 26: 23-24.

Dixon P.S. 1970. The Rhdophyta: Some aspects of their biology II. Oceanogr. Mar. Biol. Annu. Rev. 8: 307-352.

Edwards P. 1970. Field and cultural observations on the growth and reproduction of Polysiphonia denudata from Texas. $\mathrm{Br}$. Phycol. J. 5: 145-153.

Garbary D.J., Grund D., and Mclachlan J. 1978. The taxonomic status of Ceramium rubrum (Huds.) C. Ag. (Rhodophyta, Ceramiales) based on culture experiments. Phycologia 17: 85-94.

Hanisak D.M. and Blair S.M. 1988. The deep water microalgal community of the East Florida continental shelf (USA). Helgoland. Wiss. Meeresunters. 42: 133-163.

Hoyle M.D. 1978. Reproductive phenology and growth rates in two species of Gracilaria from Hawaii. J. Exp. Mar. Biol. Ecol. 35: 273-283.

Kaliaperumal N. and Umamaheswara Rao M. 1982. Seasonal growth and reproduction of Gelidiopsis variabilis (Greville) Schmitz. J. Exp. Mar. Biol. Ecol. 61: 265-270.

Kaliaperumal N. and Umamaheswara Rao M. 1985. Seasonal growth, reproduction and spore shedding in Pterocladia heteroplatos. Proc. Indian Acad. Sci. (Plant Sci.). 94: 627-632.

Kaliaperumal N. and Umamaheswara Rao M. 1986. Growth, reproduction and sporulation of marine alga Gelidium pusillum. (Stackhouse) Lejolis. Indian J. Mar. Sci. 15: 29-32.

Kapraun D.F. 1977. Asexual propagules in the life history of Polysiphonia ferulacea (Rhodophyta, Gigartinales). Phycologia 16: 417-426.

Kapraun D.F. 1978. Field and cultural studies on selected north Carolina Polysiphonia species. Bot. Mar. 21: 143-153.

Mathieson A.C., Hehre E.H. and Reynolds N.B. 1981. Investigations of New England marine algae. 1. A floristic and descriptive ecological study of the marine algae at Jaffrey Point, New Hampshire, USA. Bot. Mar. 24: 521-532.

Montalva S. and Santalices B. 1981. Interspecific interference among species of Gelidium from Central Chile. J. Exp. Mar. Biol. Ecol. 53: 77-88.

Mshigeni K.E. 1976. Studies on the reproduction of selected species of Hypnea (Rhodophyta, Gigartinales) from Hawaii. Bot. Mr. 19: 341-346.

Rama Rao K. 1977. Studies on Indian Hypneaceae. II. Reproductive capacity in the two species of Hypnea over the different seasons. Bot. Mar. 20: 33-39.

Rama Rao K. and Thomas P.C. 1974. Shedding of carpospores in Gracilaria edulis. (Gmel.) Silva. Phykos 13: 54-59.

Reynolds N.B. and Mathieson A.C. 1975. Seasonal occurrence and ecology of marine algae in a New Hampshire tidal 
rapid. Rhodora 77: 512-533.

Subba Rangaiah G. 1983. Seasonal growth, reproduction and spore shedding in Gracilaria corticata. J. Ag. of the Visakhapatnam Coast. Proc. Indian Natl. Sci. Acad. B. 49: 711-718.

Subba Rangaiah G. 1984. Growth, reproduction and spore shedding in Gracilaria textorii (Sur.) J. Ag. of the Visakhapatnam Coast. Phykos 23: 246-253.

Subba Rangaiah G. 1985. Spore shedding in Gracilariopsis sjoestedtii (Kylin.) Dawson. (Rhodophyta, Gigartinales). Proc. All Ind. Symp. Mar. Plants Donapaula. Goa. pp. 59-64.

Subba Rangaiah G. and Umamaheswara Rao M. 1983. Seasonal growth, reproduction and spore shedding in Hypnea valentiae (Turn.) Mont. Proc. Indian Acad. Sci. (Plant Sci.) 92: 473482.

Subba Rangaiah G. and Vanilla Kumari E. 1997. Seasonal growth, reproduction and spore shedding in Amphiroa fragilissima (L.) Lamouroux (Rhodophyta, Cryptonemiales) of the Visakhapatnam Coast. Natl. Symp. Recent trends in Algal Research. Andhra Univ., India. 6-8 March.

Sudhakar S. 1992. Ecological studies on some Ceramiales (Rhodophyceae) of the Visakhapatnam Coast. Ph.D. thesis. Andhra Univ., Waltair. India.

Suto S. 1950. Shedding, floating and fixing of the spores of Gelidium. Bull. Jap. Soc. Sci. Fish. 15: 671-673.
Umamaheswara Rao M. 1973. Growth and reproduction in some species of Gracilaria and Gracilariopsis in the Palk Bay. Ind. J. Fish. 20: 182-192.

Umamaheswara Rao M. 1974. Observations on fruiting cycle, spore output and germination of tetraspores of Gelidiella acerosa in the Gul of Mannar. Bot. Mar. 17: 204-207.

Umamaheswara Rao M. 1976. Spore liberation in Gracilaria corticata J. Ag. growing at Mandapam. J. Exp. Mar. Biol. Ecol. 21: 91-98.

Umamaheswara Rao M. and Sreeramulu T. 1964. An ecological study of some intertidal algae of the Visakhapatnam Coast. J. Ecol. 52: 595-616.

Umamaheswara Rao M. and Sreeramulu T. 1970. The fruiting behaviour of some marine algae at Visakhapatnam. Bot. Mar. 13: 47-49.

Vanilla Kumari E. 1997. Ecological studies on some Cryptonemiales (Rhodophyta) of the Visakhapatnam Coast. Ph.D. thesis. Andhra Univ., Waltair. India.

Waern M. 1952. Rocky shore algae in the Oregrund Archipelago. Acta. Phytogeographia. Suecia 30: 298 pp.

Yarish C. and Edwards P. 1982. A field and cultural investigations of the horizontal and seasonal distribution of estuarine algae of New Jersey. Phycologia 21: 112-124.

Accepted 14 February 2003 